\title{
The Influence of Organizational Design, Work Culture, and Work Loads on Employee Satisfaction in Bekasi Branch XYZ Bank
}

\author{
Valentina Simangunsung ${ }^{1}$ \\ Mercu Buana University, Jakarta
}

\begin{abstract}
This research is motivated by the increasing technological changes, resulting in the design of the company's organization must change in order to remain able to follow market competition. Changes in organizational design also have an impact on changes in work culture and employee workload that affects job satisfaction.
\end{abstract}

The purpose of this study is to determine how much influence the changes in organizational design, work culture, and workload on employee job satisfaction, and how much changes in organizational design, work culture, and workload together affect work satisfaction.

This research was analyzed using SEM analysis. The data used in this study uses primary data obtained from employee respondents' answers. The conclusion of this study, shows that there is a significant influence between changes in organizational design, work culture, and workload on employee satisfaction at the Bekasi branch of XYZ Bank.

Based on the results of this study it is advisable to reorganize the placement of employees in branches, provide training, and motivation to employees.

Keywords:- Human Resource Management, Organizational Design Changes.

\section{INTRODUCTION}

Banking companies have an important role in the development of the country's economy that can help the country in managing its finances. The bank is a financial institution that is also a financial stability in Indonesia and is also a company driving the circulation of money in the country, besides that the bank also has a role in facilitating financial transactions for the public and other companies.

XYZ Bank was founded in 1957, it is one of the largest private banks in Indonesia serving a variety of customer segments, both individuals and organizations. To be able to compete with other banking industries, Bank XYZ has a competitive advantage that will only be obtained from employees who are productive, innovative, creative, always enthusiastic, and loyal.

\author{
Dr. Kasmir, SE., MM² \\ Mercu Buana University, Jakarta
}

Employee job satisfaction based on wages and facilities at XYZ Bank is no doubt because it is always transparent to the overall achievements and open to the public, but job satisfaction can not only be measured in terms of the financials received but there are other things that also influence.

The results obtained indicate that banking customers in Indonesia are very enthusiastic to adopt digital banking technology. This phenomenon is the reason for this XYZ Bank to make organizational design changes that lead to the development of digital services. These changes are expected to improve employee performance in providing services to customers digitally, however, not all changes get a positive response, especially in the company's internal because these changes lead to changes in the ways and means chosen by the company to survive. To improve this performance employee job satisfaction is needed first, because satisfied employees will be able to form positive performance (Robbins, 2008: 37).

From the observations of 25 non-management employees interviewed there were 20 employees who were dissatisfied with various reasons and after screening the dissatisfied employees chose the most reason for the variable changes in organizational design by 4 employees with a percentage of $20 \%$, changes in work culture by 6 employees with a percentage of $30 \%$, and an increase in workload of 7 employees dissatisfied with the percentage of $35 \%$ of all correspondents.

Changes in the organizational culture also cause problems in the workload, where the workload is increasing and employees are required to be able to work in teams but more specifically work individually (efficiently).

\section{LITERATURE REVIEW}

\section{A. Organizational Design}

According to Ivancevich, Konopaske, and Matteson (2007: 236). "Organizational design is an organizational structure formed by the manager of the organization which is at the same time a result of managerial decisions and actions." 
According to Dicky Wisnu (2019: 10). " Organizational design is the way and the reasons for the various means chosen by managers to balance the pressures from outside the organization. " According to Daft (2005: 15) states the dimensions of organizational design consists of two namely:

1 Structural Dimensions are dimensions that create a basis for measuring and comparing organizations by describing the internal characteristics of the organization.

2 The contextual dimension is the dimension that describes the whole of an organization. This dimension shapes and influences the organizational structure by showing the organizational structure.

\section{B. Work Culture}

Work culture according to Mangkunegara (2012) defines that work culture is a code of conduct for members in organizations in the form of belief systems, values, and norms to overcome internal and external problems.According to Triguno (2011) work culture is a trait, habit and driving force in the life of a community or organization based on a view of life which is then reflected from attitudes into behavior, beliefs, ideals, opinions and actions that are realized. 3D Dimensions and Indicators of Work Culture.

The dimensions and indicators of work culture according to Robbins in Ichsan Nugraha (2016), namely:

a. Result orientation with target achievement indicators

b. Human orientation with indicators of the company's attention to the comfort of work, recreation, etc.

c. Team orientation with indicators of cooperation and tolerance that occur between company employees.

d. Innovate and take risks with the support and work atmosphere for creativity, respect for employee aspirations, and employee responsibilities towards the company.

\section{Workload}

According to Danang Sunyoto (2012: 64), workload is a stress faced by a person in work due to a person's selftension in facing a given job.

According to Meshkati in Tarwaka (2011), workload can be defined as a difference between the capacity or ability of workers with the work demands that must be faced.According to Harry G et al in Tarwaka (2014: 131) states that the dimensions and indicators of the workload are as follows:

a. Time load:

1) Barriers / interference with the environment when doing work

2) Working time period. / Working time demands

b. Mental effort load (mental effort load):

1) Frequency of work arrivals,

2) The level of concentration in carrying out the task.

c. Psychological stress load:

1) job risk level

2) confusion and frustration.

\section{Job satisfaction}

According to Robbins (2015: 170) stated that job satisfaction is a general attitude towards one's work as a difference in expectations desired by workers with work received.

According to Lawler (in Robbins, 2015: 180), a measure of satisfaction is very based on the reality faced and accepted as compensation for the effort and energy provided. Job satisfaction depends on the suitability or balance between the expected and reality.

Factors that affect job satisfaction, according to Mangkunegara (2015: 120), namely:

a) Employee factors, namely intelligence (IQ), special skills, age, gender, physical condition, education, work experience, years of service, personality, emotions, ways of thinking, perceptions, and work attitudes.

b) Job factors, namely the type of work, organizational structure, rank (class), position, quality of supervision, financial security, job promotion opportunities, social interaction, and work relations.

\section{THEORETICAL FRAMEWORK}

Job satisfaction is a happy feeling of employees that arises after comparing the perception of work results with expectations. Job satisfaction often affects the conditions of employees to complete their obligations. Employees who are dissatisfied will certainly affect the way they work and the environment and not least give a negative impact on other employees and will certainly affect the performance of each employee and will have an effect on organizational performance. Therefore, employee job satisfaction is an important factor for the company to keep developing, because with satisfied employees, the company can have the support of employees to be able to make innovations that can benefit the organization.

Based on the description above, the framework of thinking in this study is as follows:

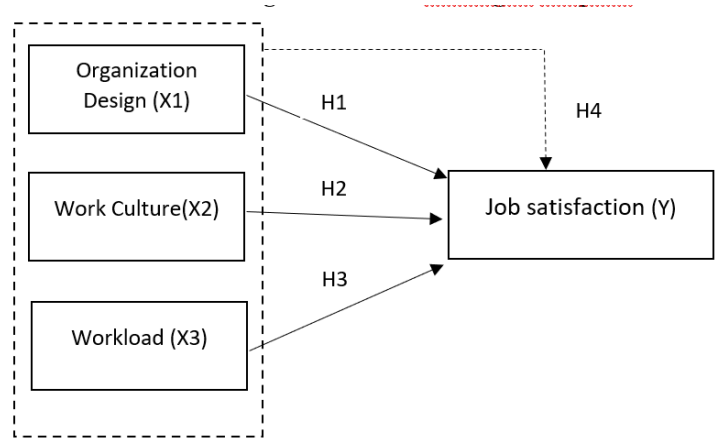

Fig 1:- Theoretical Framework

\footnotetext{
$>$ Research Hypothesis

H1: Organizational design influences employee job satisfaction

H2: Work culture has an effect on employee job satisfaction

H3 : Workload affects employee job satisfaction
} 
H4 : Organizational design, work culture and workload have a joint effect on employee job satisfaction

\section{SAMPLES AND POPULATIONS}

The population in this study were all permanent employees at one private bank in Bekasi. This population amounts to 100 employees from all sections.

Based on this study because the population is not greater than 100 correspondents, the authors took a sample of $100 \%$ of the population in one of the Private Banks in Bekasi, as many as 100 correspondents or known as the Saturated Sample.

\section{METHOD OF COLLECTING DATA}

Data were collected using a questionnaire method that is by giving a list of questions or questionnaires directly to the respondents. The questionnaire is a closed questionnaire consisting of two parts, namely the first part consisting of questions to obtain respondent's personal data and the second part is used to obtain data about the dimensions of the constructs developed in this study. Statements in closed questionnaires are made using a scale of 1-5 to obtain interval data and are given a score or score, for example for the category of statements with answers that strongly disagree or strongly agree.

\section{DATA ANALYSIS METHOD}

The research model that will be used in this study is a tiered structure model and to test the proposed hypothesis used SEM (Structural Equation Modeling) analysis techniques that are operated through the AMOS program. The advantage of SEM application in management research is because of its ability to confirm the dimensions of a concept or factor that is very commonly used in management as well as its ability to measure the influence of relationships that theoretically exist (Augusty T. Ferdinand, 2000, p. 5). Furthermore, AMOS (Arbuckle, 1997) is used in this study because it has the ability to:

a) Estimates unknown coefficients from Linear structural equations.

b) Includes a model that contains latent variables

c) Contains error measurements for both the dependent and independent variables.

d) Measure the direct and indirect effects of the dependent and independent variables.

e) Contains reciprocal, simultaneous (simultaneous), and interdependent causal relationships.

\section{RESULTS AND DISCUSSION}

The test of the full feasibility of the SEM model was tested using Chi square, GFI, CFI, TLI, CMIN / DF and RMSEA within the expected value range, although AGFI was marginally accepted and the results of the analysis showed that the model had not been fit then the model was modified so that reach the Fit model.

\section{A. Convergent Validity}

From the Evaluation of Outer Loading it can be seen that most indicators describe each of the latent variables. However, there are two indicator variables namely $\mathrm{x} 7$ and $\mathrm{x} 5$ which do not describe the work culture variable.

\section{B. Model fittings}

After removing the two variables in work culture, we get:

\begin{tabular}{|c|c|c|c|}
\hline $\begin{array}{c}\text { Goodness of } \\
\text { fit index }\end{array}$ & $\begin{array}{c}\text { Cut-of } \\
\text { Value }\end{array}$ & the results & Explan. \\
\hline $\begin{array}{c}\text { X2 - Chi- } \\
\text { square }\end{array}$ & $\begin{array}{c}\text { It is } \\
\text { expected } \\
\text { that a small } \\
\text { df } 0.05 ; 87 \\
=109,773\end{array}$ & 122.0867 & marginal \\
\hline $\begin{array}{c}\text { Significance } \\
\text { Probability }\end{array}$ & $\geq 0.05$ & 0.001 & Poor Fit \\
\hline RMSEA & $\leq 0.08$ & 0.093 & marginal \\
\hline GFI & $\geq 0.90$ & 0.649 & marginal \\
\hline AGFI & $\geq 0.90$ & 0.502 & marginal \\
\hline CMIN / DF & $\leq 2.00$ & 1.402299 & Fit \\
\hline TLI & $\geq 0.95$ & 0821 & marginal \\
\hline CFI & $\geq 0.95$ & 0838 & marginal \\
\hline
\end{tabular}

Table 1:- Model Feasibility Test (Fitting Model)

\section{Data Normality}

Based on the calculation results, all indicators of the critical ratio skewness value are below \pm 2.58 . Data from indicators are normally distributed and are suitable for use.

\section{Evaluation of Multicollinearity and Singularity.}

From the results of data processing the determinant value of the sample covariance matrix is;

Determinant of sample covariance matrix $=1,880$

From the results of data processing it can be seen the determinant value of the sample covariance matrix is far from zero. Thus it can be said that the research data used do not have multicollinearity and singularity.

\section{E. Reliability and Variance Extract Test}

\begin{tabular}{|l|l|r|l|}
\hline \multicolumn{2}{|c|}{ variance Extract Variabel } & Realibility & $\begin{array}{c}\text { Varian } \\
\text { Exc }\end{array}$ \\
\hline $\begin{array}{l}\text { Organization } \\
\text { Design }\end{array}$ & $\begin{array}{l}\text { Organization } \\
\text { Design } \\
\text { Work Culture }\end{array}$ & 0.64 & 0.27 \\
Work_Culture & 0.77 & 0.31 \\
\hline
\end{tabular}

Table 2: Reliability and Variance Extract

The results of reliability testing and variance extract on each latent variable on the dimensions of its formation indicate that all variables show as a reliable measure because each has a reliability greater than 0.6. 
The variance extract test results have also shown that each latent variable is the result of a fairly large extraction of its dimensions. This is indicated by the variance extract value of each variable is more than 0.4 .

\section{RESEARCH DISCUSSION}

Based on the results of data analysis and observations that have been made, it can be disclosed research discussions about the effect of changes in organizational design, work culture, and workload on employee job satisfaction at one of the Private Banks in Bekasi Branch, as follows:

\section{$>$ Effect of changes in organizational design (X1) on employee job satisfaction $(Y)$}

Based on the results of the study, it can be proven that there is an influence between organizational design on employee job satisfaction at one of the Private Banks in Bekasi. In general, organizational design or work design applied at the Private Bank is classified as good with the hypothesis test results of 0.024 in the estimate column, which means there is a positive influence between changes in organizational design on job satisfaction, where if organizational design changes are improved, it can increase employee job satisfaction by $2,4 \%$ overall.

Workman and Bommer (2004: 317-337) in Irsan said, a motivational approach to organizational design seeks to enhance employee feelings and attitudes such as job satisfaction and intrinsic motivation as well as the results of key behaviors such as absenteeism, stopping, and performance.

Based on the estimation results, the biggest indicator of this organizational design change is in X1 and X4 with an estimated value of 2.1 , which is the division of tasks that is in accordance with the integrated company structure and between divisions based on changes in organizational work policies to keep up with world developments banking today where technology dominates the banking system and workings. Changes in the way work is done by almost all divisions within the bank and the effects are seen in accordance with the results of the questionnaire in which the operational division is the most division that is experiencing the impact of organizational design changes. An operational concern in this regard lies in the large number of machines being used as a substitute for employees. One example is the cash deposit machine at the nearest ATM to the customer's location, currently customers do not need to come to the bank to deposit money if the deposit is below 30 million per day, and at the branch office found two machines that can be operated by one teller employee. From this picture it can be seen that the use of machines is currently somewhat more and the optimization of employees is decreasing wherein the current appointment of employees even the contract extension of employees is decreasing, and employee utilization or mutation of employees to other parts is increasing.
This study supports previous research by Juan Meng, Bruce K, Berger in 2018 with the title "The Impact of Organizational Culture and Leadership Performance on PR Job Satisfaction Professionals," Testing the Joint Mediating Effects of Engagement and Trust. Get confirmation that changes in organizational design have a strong effect on employee job satisfaction. This is based on the existence of technological changes that quickly give effect to communication which is also fast-changing, these changes can affect the workings and focus of employees so as to make employees must be familiar with new work patterns, this causes some employees to have positive responses but some employees respond to this problem and become a challenge because the workload faced will increase.

Also this argument is reinforced by the existence of previous research by Arto Suharto Prawirodirjo (2007) where it is said that changes in organizational design occur followed by changes in structure, organizational goals, technology, and at the same time changing work environment. With this change employees are required to add knowledge and other skills that will affect job satisfaction.

The above results also support the results of research conducted by Sobirin (2000) who explains that organizational change is positively related to employee job satisfaction. Likewise, Dwiarti (2003) states that one of the factors that influence employee job satisfaction is organizational change, and Pantja Djati (2000) shows that organizational change affects employee job satisfaction.

\section{Effect of Work Culture (X2) on employee job satisfaction} (Y)

Based on the results of the study, it can be proven that there is an influence between work culture on employee job satisfaction in one of the Private Banks in Bekasi. In general, the work culture applied at the Private Bank is classified as good with the hypothesis test result -0.270 , which means there is a significant negative influence, where if the work culture is improved, employee job satisfaction will decrease as a whole by $27 \%$.

Based on the estimation calculation, the biggest indicator of work culture is contained in X8 with an estimated calculation value of 1 that every employee can work together in realizing the company's vision and mission. The influence is based on changes in organizational design that causes changes in the way work or work culture in the company. The existence of dissatisfaction in the implementation of work culture is the unpreparedness or unwillingness of employees to change their mindset to move forward and follow technological developments. This dissatisfaction is based on the differences in the desires of employees with the company's goals. Where employees are still accustomed to and want to work the old way while the company must spread its wings to follow current developments to be able to compete with other similar companies. 
Work culture is also believed to influence individual traits regarding commitment, motivation, morals, and job satisfaction. Thus, this research is supported by previous research conducted by Aswadi Lubis (2016) and Fenghua Song, Anjan V. Thakor (2018) that there is a positive relationship between work culture and job satisfaction.

Also this study supports previous research reported by Khuzaeni, MS Idrus Djumahir, Solimun, 2013: University of Brawijaya Malang with the title "The Influence of Work Culture, Work Stress to The Job Satisfaction and Employees Performance in the State Treasury Service Office in Jakarta, Indonesia." That work culture and work stress do not affect job satisfaction. Work culture influences employee performance and work stress does not affect employee performance. Therefore research on this variable has the aim to reexamine the relationship of work culture with job satisfaction.

\section{$>$ Effect of Workload (X3) on employee job satisfaction (Y)}

Based on the results of the study, it can be proven that there is an influence between workload on employee job satisfaction at one of the Private Banks in Bekasi. In general, the workload applied to the Private Bank is classified as good with the 0.046 hypothesis test results in the estimate column, which means there is a positive effect, where if the workload decreases, job satisfaction increases overall by $4.6 \%$.

Based on the estimation calculation, the largest indicator of workload is found in X12 with an estimated calculation value of 1 , ie work that is given suddenly in a short period of time. This has an effect on employee job satisfaction because it feels burdensome or puts pressure on employees. The term workload is often interpreted as something that is burdensome or stressful for someone's life. Workload according to Cohen is a work condition felt by workers related to situational factors consisting of physical and psychological environment factors (Nur Afrirahmiati, 2007: 19).

Workload is an individual extrinsic factor which is one of the sources of emergence of pressure, because the workload it faces is too much. This condition requires employees to provide even greater energy than usual in completing their work, but it all depends on each individual, meaning that the tasks will be completed properly or not depending on how a person feels the workload he feels.

As has been said before, that satisfaction or dissatisfaction is closely related to work activities, company productivity. Employees who are satisfied with their work are likely to be more enthusiastic at work and able to meet work targets, but employees who are dissatisfied because of their working conditions will inhibit their work activities, in other words dissatisfaction is the starting point of problems that arise in organizations such as conflict, absenteeism , turn over, and many other problems that cause disruption of the process of achieving organizational goals. On the side of workers, employee dissatisfaction will reduce work motivation, morale, loyalty to the organization and ultimately lead to a decrease in performance both qualitatively and quantitatively (Suryana Sumantri, 2001: 82).

This research is also supported by previous research, namely the relationship between workload and job satisfaction obtained by previous research by Margaritha $\mathrm{J}$ Tulangow with the title "Environment and Workload on Employee Turnover Intention (Case Study at PT Wika Reality, Manado, 2018: University of Sam Ratulangi)" have the results of this study indicate there is a significant effect of work stress, work environment, and workload on the intensity of PT Wika Reality's employee turnover, with a solution to the amount of work provided to each employee.

\section{Research Limitations}

In writing this research, the author realizes that there are still many shortcomings and is far from perfect. There are several things that become obstacles that the writer experienced, including the limitations of the author's time to reveal other factors that affect employee Job Satisfaction at one of the Private Banks in Bekasi.

\section{CONCLUSIONS,IMPLICATIONS AND RECOMMENDATIONS}

\section{A. CONCLUSION}

1 The influence between changes in organizational design on job satisfaction at one of the Private Banks in Bekasi has a positive and significant effect. Where if improvements are made to changes in organizational design, job satisfaction will increase. This proves that with the rapid technological changes that have an effect on communication that is also rapidly changing, the existence of these changes can affect the workings and focus of employees so as to make employees have to get used to new work patterns, this causes some employees to have positive responses but some employees respond to this as a problem and a challenge because the workload faced will increase. Then employees who feel burdened by this will be increasingly dissatisfied with current working conditions.

2 The influence of changes in work culture on job satisfaction at one of the Private Banks in Bekasi has a negative and significant effect. This proves that this dissatisfaction is based on differences in employee desires with company goals. Where employees are still accustomed to and want to work the old way while the company must spread its wings to follow current developments to be able to compete with other similar companies. Therefore, if improvements are made to the work culture it will make employee job satisfaction decrease.

3 The effect of changes in workload on job satisfaction at one of the Private Banks in Bekasi has a positive and significant effect. Where, if improvements are made to the workload it will increase employee job satisfaction. This proves that employees are satisfiedthe work is likely to be more enthusiastic at work and able to meet work targets, but employees who are dissatisfied because of the conditions of work, will inhibit work activities and 
burden the emotional side, in other words dissatisfaction is the starting point of problems that arise in organizations such as conflict, absenteeism, turnover, and many other problems that cause the process of achieving organizational goals are disrupted.

\section{B. Suggestion}

\section{Practical Advice For Companies}

a. Preparing employees to be ready to face changes in organizational structure or design by arranging the placement of employees in a branch with a ratio of 2: 1 where 2 old employees and 1 new employee are expected to help and have a positive impact to be able to think ahead and accept changes in organizational design

b. Creating a good work culture by providing training in team collaboration both in e-learning and consistent direct discussions, also increasing inter-branch team engagement by consistently holding inter-team competition so that it is expected to lead to good teamwork or Team Engagemen.

c. Provide motivation both from superiors and from emotional training programs to employees with the intention of changing the mindset of employees who consider work a heavy burden into an exciting game. Can also give appreciation both in the form of rewards and rewards for employees who are able to complete their duties properly and consistently.

\section{Academic Suggestions for Next Researchers}

For further researchers, it is recommended to add or use other variables that affect employee performance in addition to variables of work culture, job satisfaction and employee commitment. For example, leadership support, work competence, work priorities and others.

\section{REFERENCES}

[1]. A.A Anwar Prabu Mangkunegara (2012). Manajemen Sumber Daya Manusia. Bandung: PT. Remaja Rosdakarya.

[2]. Ali, N. M , Jangga , R., Ismail, M., Kamal, S. N.M. Influence Of Leadership Styles In Creating Quality Work Culture. Procedia Economics and Finance, 31, $161-169$

[3]. Ali, S., Farooqi, Y. A. (2014). Effect of Work Overload on Job Satisfaction, Effect of Job Satisfaction on Employee Performance and Employee Engagement (A Case of Public Sector University of Gujranwala Division). International Journal of Multidiciplinary Sciences and Engineering, 5(8), 2230.

[4]. Application in Telecommunication Sector. Procedia Social and Behavioral Sciences, 195,673 - 679.

[5]. Arbuckle, James L, 1997. Amos 7.0 User's Guide. Terjemahan. Chicago, IL: SPSS Inc.

[6]. Arikunto, Suharsimi. (2012). Prosedur Penelitian Suatu Pendekatan Praktek. Jakarta: Rineka Cipt.
[7]. Augusty Ferdinand, Metode Penelitian Manajemen: Pedoman Penelitian untuk Skripsi, Tesis dan Disertasi Ilmu Manajemen, Semarang: Badan Penerbit Universitas Diponegoro. 2006

[8]. Barron, A., Pereda, A., Stacey, S. (2016). Exploring the performance of government affairs subsidiaries: A study of organisation design and the social capital of European government affairs managers at Toyota Motor Europe and Hyundai Motor Company in Brussels. Journal of World Business, 1-13.

[9]. Belias, D., Koustelios., A, Vairaktarakis., G, Sdrolias L. (2015). Organizational Culture and Job Satisfaction of Greek Banking Institutions. Procedia - Social and Behavioral Sciences, 175, 314 - 32

[10]. Bushman, R. M., Davidson, R. H., Dey, A., Smith, A. (2018). Bank CEO materialism: Risk controls, culture and tail risk. Journal of Accounting and Economics, 65, 191-220.

[11]. Cetin, M., Karabay, M. E., Efe, M. N. (2012). The Effect Of Leadership Styles and The Communication Competency of Bank Managers on The Employee's Job Satisfaction: The Case of Turkish Banks. Procedia Social and Behavioral Sciences, 58, 227-235.

[12]. Cooper, Donald R., dan Emory, William C.. (1997).Metode Penelitian Bisnis. Erlangga, Jakarta.

[13]. Daft Richard L, 2005. Organization Management and Industrial Relations. Prentice- Hall, Inc : New Jersey.

[14]. Danang, Sunyoto. 2012. Manajemen Sumber Daya Manusia. Jakarta: PT Buku Seru.

[15]. Dhania, D. R. (2010). Pengaruh Stress Kerja, Beban Kerja Terhadap Kepuasan Keja (Studi pada Medical Representatif di Kota Kudus). Jurnal Psikologi Universitas Muria Kudus, 1(1), 15-2

[16]. Ferdinand, Augusty.(2000). Manajemen Pemasaran : Sebuah Pendekatan Stratejik, Research Paper Series. Seri Penelitian Manajemen, No. 01/Mark/01/2000.

[17]. Griffin, 2004. Komitmen Organisasi, Terjemahan, Jakarta: Erlangg

[18]. Habib, S., Aslam, S., Hussain, A., Yasmeen, S, Ibrahim, M. (2014). The Impact of Organizational Culture on Job Satisfaction, Employess Commitment and Turn over Intention. Advances in Economics and Business 2(6), 215-22

[19]. Hair J.F. et.al (1995), "Multivariate Data Analysis With Reading", Fourth Edition,

[20]. Terjemahan. Prentice Hall. New Jersey

[21]. Hakim, Lukman, 2014, Dasar-Dasar Manajemen, Surakarta: Jasmine

[22]. Indriantoro, Nur, dan Bambang Supomo, 1999, Metodologi Penelitian dan Bisnis, Yogyakarta: BPFE Yogyakarta.

[23]. Ivancevich, John M, Konopaske Robert \& Matteson Michael T 2007, Perilaku Dan Manajemen Organisasi (Alih Bahasa Gina Gania), Edisi Tujuh. Jakarta:Erlangga

[24]. Kayaga, S. M, Kingdom, W, Jalakam, A. (2017). Organisational design for improved performance of urban water utilities in developing countries. Utilities Policy. 1-11. 
[25]. Khuzaeni, Idrus, M., S., Solimun, D. (2013). The Influence of Work Culture, Work Stress to the Job Satisfaction and Employees Performance in the State Treasury Service Office in Jakarta, Indonesia. IOSR Journal of Business and Management (IOSR-JBM) eISSN: 2278-487X, p-ISSN: 2319-7668. Volume 9, Issue 2, 49-5

[26]. Lubis, A. (2016). Pengaruh Budaya Kerja dan Gaya Kepemimpinan Terhadap Kepuasan Kerja Pegawai Administrasi Lain di Padang Sidempuan. Jurnal Penelitian Ilmu-ilmu Sosial dan Keislaman p-ISSN: 2442-7004, 2(2), 157-171.

[27]. Mahanani, I., W., Lubis, N., Widiartanto. Pengaruh Budaya Kerja dan Kepuasan Kerja Terhadap Kinerja Karyawan dengan Komitmen Karyawan Sebagai Variabel Antara (Studi Kasus pada Karyawan Bagian Produksi Cetak Surat Kabar PT. Masscom Graphy Semarang. Jurnal Ilmu Administrasi Bisnis.) 1-11.

[28]. Meng, J., Berger, B. K. (2018) . The Impact Of Organizational Culture and Leadership Performance On PR Professional's Job Satisfaction:Testing The Joint Mediating Effects Of Engagement and Trust. Public Relation Review. $1-12$.

[29]. Nuraini. (2015). Pengaruh Penerapan Struktur Organisasi Terhadap Kepuasan Kerja Karyawan (Studi Kasus pada PT Citraciti Pasific Pekanbaru). Jom FISIP 2(2), 1-8.

[30]. Pabundu Tika, Moh.. 2012. Budaya Organisasi dan Peningkatan Kinerja Perusahaan. Jakarta:Bumi Aksara.

[31]. Poluakan, F. A. (2016). Pengaruh Perubahan dan Pengembangan Organisasi Terhadap Kinerja Karyawan PT. Sinar Galesong Prima Manado. Jurnal EMBA ISSN 2303- 1174, 4(3). 1057 - 1067.

[32]. Priansa, Donni Juni. 2014. Perencanaan dan Pengembangan Sumber Daya Manusia. Bandung: Alfabeta

[33]. Purbaningrat, P. M., Surya, I. D. K. (2015). Pengaruh Beban Kerja Terhadap Kepuasan Kerja dengan Stress Kerja Sebagai Variabel Mediasi. E-Jurnal Manajemen Unud, 4 (5), 1149-1165.

[34]. Rizqina, Z, A., Adam, Chan., S. (2017). Pengaruh Budaya Kerja, Kemampuan, dan Komitmen Kerja Terhadap Kepuasan Kerja Pegawai serta Dampaknya Terhadap Kinerja Badan Pengusahaan Kawasan Perdagangan dan Pelabuhan Bebas Sabang (BPKS). Jurnal Magister Manajemen ISSN 2302-0199 Fakultas Ekonomi dan Bisnis Unsyiah, 1(1), 59-69.

[35]. S.P ,Hasibuan, Malayu. 2013. Manajemen Sumber Daya Manusia. Jakarta: PT Bumi Aksara

[36]. Saner, T., Eyupoglu, S. Z. (2015). The Job Satisfaction Of Bank Employee In North Cyprus. Procedia Economics and Finance, 23, 1457 - 1460.

[37]. Stephen, Robbins.2015. Perilaku Organisasi. Jakarta: Salemba Empat

[38]. Sugiyono. (2016). Metode Penelitian Kuantitatif, Kualitatif dan R\&D. Bandung: PT Alfabet.

[39]. Sugiyono. (2017). Metode Penelitian Kuantitatif, Kualitatif, dan R\&D. Bandung : Alfabeta, CV

[40]. Sugiyono. 2012. Metode Penelitian Kuantitatif Kualitatif dan R\&D. Bandung: Alfabeta.
[41]. Supriyadi Gering dan Triguno. (2011). Budaya Kerja Organisasi Pemerintah. Jakarta.

[42]. Tambengi, F. S., Kojo, C., Rumokoy, F.S. (2016). Pengaruh Kompensasi, Beban Kerja, dan Pengembangan Karir Terhadap Kepuasan Kerja Karyawan pada PT Telekomunikasi Indonesia, Tbk (Witel Sulut). Jurnal EMBA 4(4), 1088 - 1097

[43]. Tarwaka. 2011. Dasar-Dasar Pengetahuan Ergonomi dan Aplikasi di Tempat Kerja. Surakarta: Harapan Press

[44]. Tepret N.Y., Tuna K. (2015). Effect of Management Factor on Employee Job Satisfaction: An

[45]. Thomas, O. O. (2015). Effect of Organizational Structure on Job Satisfaction in the Nigerian Financial Sector : Insight From Selected Banks in Lagos State. NG-Journal of Social Development, 5, 96-108.

[46]. Tulangow, M. J., Saerang, D.. P.. E., Rumokoy, F. S. (2018). The Effect of Job Stress, Work Enviromnent and Workload on Employee Turnover Intention (Case Study at PT. Wika Reality Manado). Jurnal EMBA ISSN 2303-1174, 6 (2), 474 - 482.

[47]. Wibisono, Y., Wahyuni, S. (2015). Dampak Laju Perubahan Organisasional Terhadap Kepercayaan dan Sikap Karyawan: Studi Kasus Pada PerusahaanPerusahaan Teknologi Informasi dan Komunikasi. Jurnal Manajemen Teknologi. 14(1), 81-99.

[48]. Wijaya, A. (2018). Pengaruh Beban Kerja Terhadap Kepuasan Kerja dengan Stress Kerja Sebagai Variabel Mediasi pada Pekerja Hotel Maxone di Kota Malang, Parsimonia, 4 (3), 278-288.

[49]. Zhao, X., Hwang, B. G, Jane, L. (2019). Job Satisfaction of Project Managers in Green Construction Projects: Constituents, Barriers, and Improvement Strategies. Journal Pre-proof. 1-38

[50]. Siregar, S. (2014). Pengaruh Disiplin Kerja dan Pengawasan Terhadap Keselamatan dan Kesehatan Kerja Karyawan Pada PT. Riau Crumb Rubber Factory Pekanbaru. JOM Fekon, 1-13.

[51]. Sugiyono. (2012). Memahami Penelitian Kualitatif'. Bandung : Alfabeta. 